\title{
Investigation of Prospective Teachers' Beliefs Towards Authentic Assessment
}

\author{
İsmail Kinay ${ }^{1, *}$ \\ ${ }^{1}$ Faculty of Education, Dicle University, Diyarbakır, Turkey \\ "Correspondence: İsmail Kinay, Faculty of Education, Dicle University, Diyarbakır, Turkey. Tel: \\ 90-412-241-1000/8850. E-mail: ismailkinay84@gmail.com
}

Received: January 18, $2018 \quad$ Accepted: February 10,2018 Online Published: February 22, 2018

doi:10.5430/wje.v8n1p75 URL: https://doi.org/10.5430/wje.v8n1p75

\begin{abstract}
The aim of this study is to examine the prospective teachers' beliefs toward authentic assessment in relation to various variables. The survey method has been used in this study and the sample of the study is comprised of 612 prospective teachers $368(60.1 \%)$ of whom are female and $244(39.9 \%)$ of whom are male. The "Authentic Assessment Belief Scale" (AABS) comprised of 17 items and 3 subscales and developed by the researcher has been used as a data collection tool. As for the analysis of the data SPSS 20.0 package program has been preferred. The prospective teachers' beliefs toward the authentic assessment in terms of gender variable has been analyzed with independent samples t-test and in terms of department and grade variables one way ANOVA has been used. 05 degree of significance is used for the analysis. In case of observing significant differences LSD postdoc test has been used to determine the source of difference and effect size has been calculated to determine the magnitude of the difference. So as to determine the level of prospective teachers' beliefs toward the authentic assessment, mean and standard deviation values have been calculated. According to the findings of the study, the prospective teachers' beliefs toward the authentic assessment have been observed to be high. Moreover prospective teachers' beliefs have been determined to differ significantly in terms of gender, grade and department variables.
\end{abstract}

Keywords: authentic assessment, belief, prospective teachers

\section{Introduction}

One of the basic features of the age we live in is that we withness rapid change and development in every field so this rapid change and development also affect the educational sciences and leading to further changes and developments. As a result so many changes take place in different parts of the field like the structure of educational programs (educational aims, content, teaching-learning process, measurement and assessment and teaching materials), teacher and student roles, classroom management etc. However one of the most highlighting change can be observed in the measurement and assessments parts of the educational context.

It is necessary to implement process-centered training and process-centered assessment approaches in education to meet the need of age we are living in. This can be achieved by re-arranging such educational system's inputs as regulations, curriculm and school equipments (Karakuş, 2006). Until recently significant changes have taken place in educational strategies. Besides the changes in teaching, the highlighting changes also take place in the assessment process and this changes show tendency for more authentic assessment methods (Svinicki, 2004). One of the new approaches to assessment is authentic assessment which combines teaching with real and complex situations and contexts. Authentic assessment, also called performance assessment, appropriate assessment, alternative assessment or direct assessment, includes various techniques such as written products, portfolios, checklists, teacher observations and group projects (Olfos \& Zulanta, 2007). So the authentic assessment is the assessment of to what degree the students can transfer their learnings to real life (Slavin, 2017). Authentic assessment first emerged as a requirement for student-centered assessment and it takes the real life situations as a basis to assess the performance (Bektaş \& Horzum, 2012; Mohamed \& Othman, 2017). So in recent years educators have started to move away from traditional assessment techniques toward authentic ones (Moorcroft, Desmarais, Hogan, \& Berkowitz, 2000). Moreover authentic assessment is becoming more and more popular due to the increasing tendency for holistic assessment of students (Aitken \& Pungur, 2004). However, in order for teachers to apply authentic assessment 
methods, firstly they need to adopt and believe in authentic assessment methods. At this point, teachers' beliefs toward authentic assessment become an important issue because beliefs refer to the adoption and acceptance of opinions (Tutar, 2016).

The teachers' and students' beliefs toward the learning and the nature of the knowledge are thought to have an effect on their decisions related to teaching-learning activities and on implementation of these educational decisions (Kaleci, 2013). Moreover Schommer (1998) also mentioned that individual beliefs toward knowledge and nature of the learning affect their performance. Therefore a better understanding of teachers' educational beliefs is required to improve the teaching practices and the potential success of educational reforms (Sang, Valcke, Van Braak \& Tondeur, 2009).

Beliefs toward human learning are important factors affecting the dynamics of learning-teaching processes. Anything that teachers exposed to in the learning-teaching process can not be considered without the opinions or beliefs of the teachers (Erdem \& Arkun Kocadere, 2015). Because teachers' beliefs influence their perceptions, judgments. The nature of the teacher candidates' beliefs is important to understand their educational decisions as the upcoming teachers of the futue (Aldrich \& Thomas, 2005). Therefore, the teachers' beliefs toward authentic assessment are thought to affect their decision related to adoption and application of this assessment approach in the future.

When the literatüre investigated, the abundant researches on beliefs have been observed (Bayder \& Bulut, 2002; Deryakulu \& Büyüköztürk, 2005; Eren, 2006; Eren, 2009; Öztuna Kaplan \& Macaroğlu Akgül, 2009; Can \& Arabacıoğlu, 2009; Eren, 2010; Boz, Aydemir \& Aydemir, 2011; Karabulut \& Ulucan, 2012; Koçak, Ulusoy \& Önen, 2012; Önen, 2012; Kaleci, 2013; Şahin \& Karaman, 2013; Duru, 2014; Bay et all., 2014; ilhan, Çetin \& Kinay, 2015; Nespor, 1987; Pajares, 1992; Kagan, 1992; Schommer, 1998; Tsai, 2002; Chan, 2004; Chan \& Elliott, 2004; Woolley, Benjamin \& Woolley, 2004; Luft \& Roehrig, 2007; Mansour, 2009; Zheng, 2009; Sang, Valcke, Braak \& Tondeur, 2009; Kinay \& Karataş, 2017; Kinay \& Han, 2017; Kinay \& Ardıç, 2017; Kinay \& Bağçeci, 2017). However among these studies no one has investigated the teachers' or prospective teachers' beliefs toward authentic assessment. As there is a deficiency of this kind of study in the literature and an increasing importance of both the authentic assessment and beliefs in the learning and teaching context, this study is thought to contribute to the educational practices and the literature.

The aim of this study is to investigate the prospective teachers' beliefs toward authentic assessment in terms of various variables. In relation to this general aim following questions related to study were explored:

1. What is the level of prospective teachers' beliefs toward authentic assessment?

2. Is there a significance difference among prospective teachers' beliefs in terms of gender, grade and department variables?

\section{Method}

This study aiming to determine the prospective teachers' beliefs toward authentic assessment in terms of various variables was conducted on the basis of survey method.

\subsection{The Population and Sample}

The population of this study consists of prospective teachers studying in Ziya Gökalp Education Faculty of Dicle University in the teaching year of 2014-2015. The sample of the study consisted of 368 (\%60.1) female and 244 (\%39.9) male totally 612 prospective teachers selected randomly from the different deparments of the education faculty. The distribution of the prospective teachers in relation to grade and department was presented in Table 1. 
Table 1. The Distribution of the Preservice Teachers Participated in Study in relation to Grade and Department

\begin{tabular}{llll}
\hline & & N & \% \\
\hline & Preschool Teachers & 44 & 7.2 \\
Religion and Ethics & 44 & 7.2 \\
Social Sciences & 45 & 7.4 \\
Chemistry & 25 & 4.1 \\
English Language & 30 & 4.9 \\
Turkish Language and Literature & 33 & 5.4 \\
Classroom Teachers & 31 & 5.1 \\
& History & 36 & 5.9 \\
& Science & 5.2 \\
Mathmatics & 32 & 6.5 \\
Art & 40 & 9.2 \\
German Language & 56 & 4.6 \\
Gral & Geography & 28 & 4.7 \\
& Mathmatics for Primary Schools & 29 & 6.5 \\
& Turkish Language & 40 & 16.2 \\
\hline & 2. Grade & 100 & 16.3 \\
& 3. Grade & 258 & 42.2 \\
4. Grade & 222 & 36.3 \\
& 5. Grade & 32 & 5.2 \\
Total & 612 & 100.0 \\
\hline
\end{tabular}

\subsection{Data Collection Instrument}

"Authentic Assessment Belief Scale" (AABS) developed by the researcher has been used as a data collection instrument of the study.

In the process of scale development, first of all the literature was investigated and an item pool consisting 15 items was obtained. Then the item pool was sent to 5 experts in educational sciences department to have an expert opinion. In direction of expert opinions 6 new items were added to item pool and draft scale form was applied to 466 prospective teachers of the same faculty. The data obtained was used for validity, realibility and item analysis.

Validity of the scale was first tested in terms of construct validity. Confirmatory Factor Analysis was performed for construct validty of the scale with 21 items. 4 items (5th, 6th, 13th, 18th item) were excluded from the scale because of the insufficient factor loads and then the model was tested with the remaining 17 items.

The obtained factor loads varies between .46-.88 for the Belief toward Teacher's Role (1., 2., 3., 4.), .42-.72 for the Belief toward Student's Role (7., 8., 9., 10., 11., 12), .36-.72 for the Belief toward Assessment Method (14., 15., 16., 17., 19., 20., 21.). Chi Square value of the model tested with DFA was determined to be significant $\left(x^{2}=239.62\right.$, $\mathrm{N}=466, \mathrm{df}=115, \mathrm{p}=0.00)$. The fit index values were calculated as RMSEA $=.048, \mathrm{SRMR}=.040, \mathrm{GFI}=.94, \mathrm{AGFI}$ $=.92, \mathrm{CFI}=.98, \mathrm{NFI}=.97, \mathrm{NNFI}=.98, \mathrm{x} 2 / \mathrm{df}=2.08$.

Table 2. Shows the Goodness of Fit and Accepted Fit Values

\begin{tabular}{lcc}
\hline Fit Index & Goodness of Fit & Accepted Fit \\
\hline$\chi^{2} / \mathrm{df}$ & $0 \leq \chi^{2} / \mathrm{df} \leq 2$ & $2<\chi^{2} / \mathrm{df} \leq 3$ \\
$\mathrm{RMSEA}$ & $0 \leq \mathrm{RMSEA} \leq .05$ & $.05<\mathrm{RMSEA} \leq .08$ \\
SRMR & $0 \leq \mathrm{SRMR} \leq .05$ & $.05<\mathrm{SRMR} \leq .10$ \\
$\mathrm{NFI}$ & $.95 \leq \mathrm{NFI} \leq 1.00$ & $.90 \leq \mathrm{NFI}<.95$ \\
$\mathrm{NNFI}$ & $.97 \leq \mathrm{NNFI} \leq 1.00$ & $.95 \leq \mathrm{NNFI}<.97$ \\
$\mathrm{CFI}$ & $.97 \leq \mathrm{CFI} \leq 1.00$ & $.95 \leq \mathrm{CFI}<.97$ \\
GFI & $.95 \leq \mathrm{GFI} \leq 1.00$ & $.90 \leq \mathrm{GFI}<95$ \\
AGFI & $.90 \leq \mathrm{AGFI} \leq 1.00$ & $.85 \leq \mathrm{AGFI}<.90$ \\
\hline
\end{tabular}

(References: Schermelleh-Engel, Moosbrugger \& Müller 2003) 
When the values in Table 2 was taken into consideration, CFA yielded indications of a good fit for the proposed model.

Cronbach Alpha reliability coefficient was calculated for the realibility of the AABS. The Cronbach Alpha reliability coefficients were calculated as .83 for the Belief toward Teacher's Role dimension, .77 for the Belief toward Student's Role dimension, .76 for the Belief toward Assessment Method dimension, and .89 for the total of the scale. Scales with reliability coefficients of .70 and above can be considered reliable (Pallant, 2005; Büyüköztürk, 2011; Fraenkel, Wallen \& Hyun, 2012). According to this, the reliability coefficients of AABS and all sub-dimensions can be said to be sufficient.

Corrected item-total correlation for the item discrimination of AABS was calculated. The Pearson Moments Correlation Coefficient was used to calculate the item-total correlation. According to results of analysis, item discriminating index were found between .422-.723 for Belief toward Teacher's Role dimension, .393-579 for Belief toward Student's Role dimension, and .284-.585 for Belief toward Assessment Method dimension.

\subsection{Data Analysis}

The data obtained from the study were analyzed using the SPSS 20.0 package program. The descriptive analysis technique like percentages and frequencies were calculated in order to determine the characteristics of the prospective teachers participating in the research. As for determining the prospective teachers' beliefs toward authentic assessment the mean and standard deviation values were calculated. The mean values were interpreted based on the score ranges and levels shown in Table 2.

Table 3. Score Ranges and Levels Used to Interpret Mean Values

\begin{tabular}{ll}
\hline Score Ranges & Levels \\
\hline $1.00-1.80$ & Very Low ( Strongly Disagree) \\
$1.81-2.60$ & Low (Disagree) \\
$2.61-3.40$ & Orta (Partly Agree) \\
$3.41-4.20$ & High (Agree) \\
$4.21-5.00$ & Very High (Strongly Agree) \\
\hline
\end{tabular}

The prospective teachers' beliefs toward the authentic assessment in terms of gender variable was analyzed with independent samples t-test and in terms of department and grade variables one way ANOVA was used. 05 degree of significance was used for the analysis. In case of significance difference was obtained, the LSD postdoc test was used to determine the source of the difference and effect size was calculated to determine the magnitude of the difference. As Chone (1988) mentioned, Eta squared value between .01 and .06 is low, between .06 and .14 is moderate, and .14 and above is the high effect (as cited in Pallant, 2005; Akbulut, 2010).

\section{Findings}

The findings obtained through this study is presented in line with reseach questions. Findings regarding the levels of prospective teachers' beliefs toward authentic assessment are presented in Table 4.

Table 4. Mean and Standard Deviation Values Regarding to Prospective Teachers' Beliefs toward Authentic Assessment

\begin{tabular}{lllll}
\hline & $\mathbf{n}$ & $\mathbf{M}$ & sd & Level \\
\hline Belief toward Teacher's Role & 612 & 4.23 & .83 & Very High \\
Belief toward Student's Role & 612 & 3.99 & .83 & High \\
Belief toward Assessment Method & 612 & 4.02 & .69 & High \\
Belief toward Authentic Assessment (Total of the scale) & 612 & 4.06 & .67 & High \\
\hline
\end{tabular}

When the arithmetic mean scores and levels in Table 4 are examined, it is seen that prospective teachers have a high level of beliefs toward authentic assessment. However, it has been determined that the beliefs toward teacher's role 
dimension is at a very high level, dimensions of beliefs toward student's role and beliefs toward assessment method is at high level. Findings regarding to prospective teachers beliefs toward authentic assessment in terms of gender variable are presented in Table 5.

Table 5. The Results of Independent Sample t-test Scores Regarding to Prospective Teachers' Beliefs Towards Authentic Assessment Based on Gender Variance

\begin{tabular}{lllllllll}
\hline & Gender & $\mathbf{n}$ & $\mathbf{M}$ & sd & df & $\mathbf{t}$ & $\mathbf{p}$ & $\begin{array}{l}\text { Effect } \\
\text { size }\end{array}$ \\
\hline Belief toward Teacher's Role & Female & 368 & 4.33 & .74 & \multirow{2}{*}{610} & 3.533 & $.000^{*}$ & .022 \\
& Male & 244 & 3.44 & .93 & & & & \\
Belief toward Student's Role & Female & 368 & 4.05 & .87 & 610 & 2.200 & $.028^{*}$ & .008 \\
& Male & 244 & 3.90 & .77 & & & & \\
Belief toward Assessment Method & Female & 368 & 4.09 & .65 & 610 & 3.031 & $.003^{*}$ & .015 \\
Belief toward Authentic Assessment & Male & 244 & 3.92 & .72 & & & & \\
(Total of the scale) & Female & 368 & 4.13 & .64 & 610 & 3.353 & $.001^{*}$ & .018 \\
\hline
\end{tabular}

$(* \mathrm{P}<0,05)$

When Table 5 is examined, it is seen that there is a significant difference between prospective teachers' beliefs toward authentic assessment in terms of gender variable. When we look at the effect size of the differences, it has been determined to have a low level of significant differences. In line with these findings it can be said that gender has a meaningful effect on prospective teachers' beliefs toward authentic assessment. Findings regarding to prospective teachers beliefs toward authentic assessment in terms of grade variable are presented in Table 6 .

Table 6. Findings Regarding to Prospective Teachers Beliefs toward Authentic Assessment in terms of Grade Variable

\begin{tabular}{lllllllll}
\hline & Grade & N & M & sd & F & p & $\begin{array}{l}\text { Effect } \\
\text { Size }\end{array}$ & $\begin{array}{l}\text { LSD } \\
\text { Test }\end{array}$ \\
\hline Belief toward & 2. Grade & 100 & 4.25 & .72 & & & & \\
Teacher's Role & 3. Grade & 258 & 4.26 & .86 & 5.937 & $.001^{*}$ & .028 & $2-5,3-5,4-5$ \\
& 4. Grade & 222 & 4.26 & .79 & & & & \\
& 5. Grade & 32 & 3.63 & .94 & & & & \\
Belief toward & 2. Grade & 100 & 3.98 & .79 & & & & \\
Student's Role & 3. Grade & 258 & 4.04 & .91 & 2.804 & $.039^{*}$ & .014 & $2-5,3-5,4-5$ \\
& 4. Grade & 222 & 3.99 & .76 & & & & \\
Belief toward & 5. Grade & 32 & 3.59 & .71 & & & & \\
Assessment & 2. Grade & 100 & 4.02 & .68 & & & & \\
Method & 3. Grade & 258 & 4.01 & .63 & 1.932 & .123 & & \\
B. Grade & 222 & 4.07 & .73 & & & & \\
Authentic & 5. Grade & 32 & 3.76 & .77 & & & & \\
Assessment & 2. Grade & 100 & 4.06 & .65 & & & & \\
(Total of the scale) $)$ & 3. Grade & 258 & 4,08 & .66 & 3.964 & $.008^{*}$ & .019 & $2-5,3-5,4-5$ \\
(. Grade & 222 & 4.09 & .66 & & & & \\
\hline
\end{tabular}

When Table 6 is examined, it is seen that there is a significant difference in all dimensions except from the dimension of Belief toward Assessment Method in terms of grade variable. Apart from this there is a significant difference in total scores of the prospective teachers' beliefs toward authentic assessment in terms of grade variable. When we look at the effect size of the differences, it has been determined to have a low level of significant differences. So variable of grade can be said to have a meaningful effect on prospective teachers' beliefs toward authentic assessment. As for the department variable, findings regarding to prospective teachers beliefs toward authentic assessment are presented in Table 7. 
Table 7. Findings Regarding to Preservice Teachers Beliefs toward Teachers' Role in terms of Department Variable

\begin{tabular}{|c|c|c|c|c|c|c|c|}
\hline Department & $\mathbf{N}$ & $\mathrm{M}$ & sd & $\mathbf{F}$ & $\mathbf{p}$ & $\begin{array}{l}\text { Effect } \\
\text { Size }\end{array}$ & $\begin{array}{l}\text { LSD } \\
\text { Test }\end{array}$ \\
\hline (1) Preschool & 44 & 4.20 & .90 & & & & \multirow{15}{*}{$\begin{array}{l}1-4,1-5,2-4,2-7,3-4 \\
4-5,4-6,4-8,4-9,4-10 \\
4-11,4-12,4-13,4-14 \\
4-15,5-7,5-8,5-12 \\
5-13,7-11,7-14,7-15\end{array}$} \\
\hline (2) Religion and Ethics & 44 & 4.40 & .65 & & & & \\
\hline (3) Social Sciences & 45 & 4.26 & .81 & & & & \\
\hline (4) Chemistry & 25 & 3.54 & .91 & & & & \\
\hline (5) English Language & 30 & 4.59 & .33 & & & & \\
\hline (6) Turkish Language and Literature & 33 & 4.32 & .92 & & & & \\
\hline (7) Classroom Teachers & 31 & 3.91 & .98 & & & & \\
\hline (8) History & 36 & 4.18 & .54 & 2.548 & $.001 *$ & .056 & \\
\hline (9) Science & 32 & 4.25 & .54 & & & & \\
\hline (10) Mathmatics & 40 & 4.26 & 1.07 & & & & \\
\hline (11) Art & 56 & 4.32 & .72 & & & & \\
\hline (12) German Language & 28 & 4.04 & 1.07 & & & & \\
\hline (13) Geography & 29 & 4.04 & .96 & & & & \\
\hline (14) Mathmatics for Primary Schools & 40 & 4.31 & .53 & & & & \\
\hline (15) Turkish Language & 99 & 4.30 & .87 & & & & \\
\hline
\end{tabular}

$(* \mathrm{P}<0,05)$

When the Table 7 is examined, it is seen that there is a significant difference between prospective teachers' beliefs towards teacher's role in terms of department variable. When we look at the effect size of the differences, it has been determined to have a low level of significant differences. As for the mean values, the highest mean value belongs to the prospective teachers enrolled in English Language Teaching Department while the lowest mean value belongs to those of Chemistry Teaching Department. Findings regarding to prospective teachers beliefs toward student's role are presented in Table 8 .

Table 8. Findings of Prospective Teachers Beliefs toward Student's Role in terms of Department Variable

\begin{tabular}{llllllll}
\hline Department & N & M & sd & F & p & Effect Size $\begin{array}{c}\text { LSD } \\
\text { Test }\end{array}$ \\
\hline (1) Preschool & 44 & 3.90 & .99 & & & & \\
(2) Religion and Ethics & 44 & 4.09 & .62 & & & & \\
(3) Social Sciences & 45 & 3.96 & .73 & & & \\
(4) Chemistry & 25 & 3.58 & .75 & & & \\
(5) English Language & 30 & 4.19 & .77 & & & \\
(6) Turkish Language and Literature & 33 & 3.89 & .81 & & & \\
(7) Classroom Teachers & 31 & 3.96 & .68 & & & \\
(8) History & 36 & 4.05 & .48 & 1.226 & .251 & - \\
(9) Science & 32 & 3.99 & .59 & & & \\
(10) Mathmatics & 40 & 3.93 & .74 & & & \\
(11) Art & 56 & 4.02 & .67 & & & \\
(12) German Language & 28 & 3.86 & .92 & & & \\
(13) Geography & 29 & 3.79 & .93 & & & \\
(14) Mathmatics for Primary Schools & 40 & 3.98 & .56 & & & \\
(15) Turkish Language & 99 & 4.09 & .76 & & & \\
\hline
\end{tabular}

When Table 8 is examined, it is seen that there isn't a significant difference between prospective teachers' beliefs towards student's role in terms of department variable. As for the assessment method dimension, the findings of prospective teachers' beliefs toward it is presented in Table 9. 
Table 9. Findings Regarding to Prospevtive Teachers' Beliefs Toward Assessment Method in terms of Department Variable

\begin{tabular}{|c|c|c|c|c|c|c|c|}
\hline Department & $\mathbf{N}$ & $\mathbf{M}$ & sd & $\mathbf{F}$ & $\mathbf{p}$ & $\begin{array}{l}\text { Effect } \\
\text { Size }\end{array}$ & $\begin{array}{l}\text { LSD } \\
\text { Test }\end{array}$ \\
\hline (1) Preschool & 44 & 3.90 & .87 & \multirow{15}{*}{1.989} & \multirow{15}{*}{$.017^{*}$} & \multirow{15}{*}{.045} & \multirow{15}{*}{$\begin{array}{l}1-2, \quad 2-4, \quad 2-7, \quad 2-12, \\
2-13,4-5, \quad 4-8, \quad 4-9, \\
4-11,4-14,4-15,5-7, \\
5-13,7-9,7-11,7-14, \\
7-15,11-13\end{array}$} \\
\hline (2) Religion and Ethics & 44 & 4.21 & .47 & & & & \\
\hline (3) Social Sciences & 45 & 3.94 & .68 & & & & \\
\hline (4) Chemistry & 25 & 3.67 & .78 & & & & \\
\hline (5) English Language & 30 & 4.20 & .69 & & & & \\
\hline (6) Turkish Language and Literature & 33 & 4.02 & .77 & & & & \\
\hline (7) Classroom Teachers & 31 & 3.78 & .69 & & & & \\
\hline (8) History & 36 & 4.07 & .48 & & & & \\
\hline (9) Science & 32 & 4.16 & .45 & & & & \\
\hline (10) Mathmatics & 40 & 3.96 & .77 & & & & \\
\hline (11) Art & 56 & 4.15 & .71 & & & & \\
\hline (12) German Language & 28 & 3.87 & .67 & & & & \\
\hline (13) Geography & 29 & 3.83 & .77 & & & & \\
\hline (14) Mathmatics for Primary Schools & 40 & 4.10 & .34 & & & & \\
\hline (15) Turkish Language & 99 & 4.10 & .74 & & & & \\
\hline
\end{tabular}
$\left({ }^{*} \mathrm{P}<0,05\right)$

When we look at Table 9, it is seen that there is a significant differences between prospective teachers' beliefs toward assessment method in terms of department variable. As for the effect size of the differences, it has been determined to have a low level of significant differences. When we look at the mean values, the highest value has been observed at the prospective teachers enrolled in Religion and Ethics Department and the lowest one has been observed at those of Chemistry Teaching Department. As for the total scores of prospective teachers' beliefs toward authentic assessment in terms of department variable, the findings are presented in Table 10.

Table 10. Findings Regarding to Prospective Teachers' Beliefs toward Authentic Assessment in terms of Department Variable

\begin{tabular}{|c|c|c|c|c|c|c|c|}
\hline Department & $\mathbf{N}$ & $\mathbf{M}$ & sd & $\mathbf{F}$ & $\mathbf{p}$ & $\begin{array}{l}\text { Effect } \\
\text { Size }\end{array}$ & $\begin{array}{l}\text { LSD } \\
\text { Test }\end{array}$ \\
\hline (1) Preschool & 44 & 3.97 & .85 & \multirow{15}{*}{2.165} & \multirow{15}{*}{$.008^{*}$} & \multirow{15}{*}{.048} & \multirow{15}{*}{$\begin{array}{l}1-4,1-5,2-4,2-7,2-12, \\
2-13,3-4,4-5,4-6,4-8, \\
4-9,4-10,4-11,4-14, \\
4-15,5-7,5-12,5-13, \\
7-15,13-15,\end{array}$} \\
\hline (2) Religion and Ethics & 44 & 4.22 & .45 & & & & \\
\hline (3) Social Sciences & 45 & 4.02 & .65 & & & & \\
\hline (4) Chemistry & 25 & 3.61 & .71 & & & & \\
\hline (5) English Language & 30 & 4.29 & .54 & & & & \\
\hline $\begin{array}{l}\text { (6) Turkish Language and } \\
\text { Literature }\end{array}$ & 33 & 4.04 & .74 & & & & \\
\hline (7) Classroom Teachers & 31 & 3.87 & .63 & & & & \\
\hline (8) History & 36 & 4.09 & .39 & & & & \\
\hline (9) Science & 32 & 4.12 & .35 & & & & \\
\hline (10) Mathmatics & 40 & 4.02 & .75 & & & & \\
\hline (11) Art & 56 & 4.15 & .63 & & & & \\
\hline (12) German Language & 28 & 3.91 & .73 & & & & \\
\hline (13) Geography & 29 & 3.86 & .78 & & & & \\
\hline $\begin{array}{l}\text { (14) Mathmatics for Primary } \\
\text { Schools }\end{array}$ & 40 & 4.11 & .34 & & & & \\
\hline (15) Turkish Language & 99 & 4.14 & .70 & & & & \\
\hline
\end{tabular}
$(* \mathrm{P}<0,05)$ 
When the Table 10 is examined, a significant difference is observed between prospective teachers' beliefs toward authentic assessment in terms of department variable. As for the effect size of the differences, low level of significant difference is observed. When we look at the mean values of the prospective teachers enrolled in different departments, the highest mean value is observed at the scores of prospective teachers studying at English Language Teaching Department and the lowest mean value is observed at prospective teachers of Chemistry Teaching Department.

\section{Discussion}

In this section, the results of the study are being discussed on the basis of beliefs related to learning and education as there haven't been any literature directly related to authentic assessment beliefs.

When the findings related to the first reseach question are examined, it is seen that the prospective teachers' beliefs toward authentic assessment is high. One of the most obvious reasons of this result can be the constructivist based designs of the curriculum which was put in to practice in the year of 2005. As teaching and learning practices are influential in the formation of students' beliefs towards learning (Deryakulu, 2006). What is more, the recent studies conducted with teacher and prospective teachers have showed that teachers and prosoective teachers have quite a high level of constructivist beliefs. For instance, Bay et all (2014) and Kinay and Karataş (2017) in their studies found teachers have a high level of constructivist beliefs. Kinay and Han (2017) also found that prospective teachers had a high level of constructivist beliefs too. As a result, it can be said that the high level of belief in authentic assessment in recent studies is a result of high level of constructivist beliefs of teachers and prospective teachers.

When the findings related to the second reseach question are examined, it is seen that the prospective teachers' beliefs toward authentic assessment differ significantly according to gender variable. And also the effect size of the differences is determined to be low. So it can be said that the gender variable has an influence on the prospective teachers' beliefs toward authentic assessment. Studies on beliefs in terms of gender variable have showed different results. Considering the average mean values, it seems that the significant difference is determined to be in favor of female prospective teachers. We have come across both supporting and contradicting studies to this result in literature. Bay et all (2014) found significant differences in the constructivist beliefs and subscales of it in favor of female teachers in terms of gender variable. Moreover, Sang, Valcke, Van Braak \& Tondeur (2009) found that male teachers have more traditional learning beliefs than those of female ones. However, Kinay and Han (2017) in their study hasn't found any significant difference in preservice teachers' constructivist beliefs and its subscales in terms of gender variable. Eren (2010) and Chan, Tan and Khoo (2007) in their studies on prospective teachers' constructivist beliefs also haven't found any significant difference in terms of gender variable.

When the findings related to the second reseach question are examined, it is seen that the prospective teachers' beliefs towards authentic assessment differ significantly in all subscales except from the Belief toward Assessment Method dimension in terms in terms of grade variable. And also the effect size of the differences is determined to be low. According to this result, it can be said that the grade is an effective variable on prospective teachers' beliefs toward authentic assessment. However, previous studies have found different results on the effect of the grade variable on beliefs. For example Kinay and Han (2017) in their study have found significant difference difference in prospective teachers' constructivist beliefs in terms of grade variable. Alemdağ (2015) found that the epistemological beliefs of the prospective teachers enrolled in physical education department differ significantly in terms of grade variable. As for the study of Kinay and Ardıç (2017), they haven't found any significant difference in prospective teachers' beliefs toward standard tests in terms of grade variable.

When the findings related to the second reseach question are examined, it is seen that the prospective teachers' beliefs toward authentic assessment differ significantly in all subscales except from the Belief toward Students' Role dimension in terms of department variable. And also the effect size of the differences is determined to be low. When the mean values obtained from the whole scale are examined, it is seen that the highest mean value belongs to prospective teachers enrolled in English Language Teaching department. Studies on beliefs towards learning have identified that social constructivist dimension have the highest value among the subdimensions of the constructivist learning belief (Bay et all, 2014; Kinay \& Han, 2017; Kinay \& Karataş, 2017). As the language is seen as an important element of learning in social constructivism. So, it is an expected result that the authentic assessment beliefs of prospective teachers enrolled in English Language Teaching department is high. Kinay and Han (2017) also in their study found significant difference in prospective teachers' beliefs toward constructivist learning and the highest mean value was determined to belong to prospective teachers enrolled in Turkish Language department (Language Teaching Field). Eren $(2009,2010)$ in his studies found that the study field of prospective teachers is an 
influental variable in their beliefs toward constructivist learning. In addition, Bay et all (2014) in their study found a significant difference between classroom teachers' beliefs and branch teachers' beliefs toward traditional learning approach. Kinay and Ardıç (2017) also have found a significant difference in prospective teachers' beliefs towards standard test in terms of department variable. Finally, Can and Arabacioğlu (2009) found a significant difference in prospective teachers' epistemological beliefs in terms of department variable.

\section{Conclusion and Recommendations}

Findings obtained as a result of the research have showed that prospective teachers have a high level of authentic assessment belief. It has also been found that the variables like gender, grade and department have an significant effect on prospective teachers' beliefs toward authentic assessment. In the light of these findings following suggestions have been proposed for the future studies and implemantations:

1. As the beliefs have a valuable educational effect, more activities should be included in courses to enhance prospective teachers'authentic assessment and constructivist learning beliefs.

2. Experimental studies can be conducted with independent variables that may affect authentic assessment on prospective teachers. It is also suggested to conduct research based on correlational survey method that try to find the relations of authentic assessment with other educational beliefs.

\section{References}

Akbulut. Y. (2010). Sosyal Bilimlerde SPSS Uygulamaları. İstanbul: İdeal Kültür Yayıncılık.

Aitken, N., \& Pungur, L. (2004). Literature Synopsis: Authentic Assessment. 14.09.2013, http://education.alberta.ca/media/6412562/literature_synopsis_authentic_assessment_2004.pdf

Alemdağ, C. (2015). Pre-service Physical Education Teachers' Epistemological Beliefs, Academic Self Efficacy and Learning Approaches. Unpublished Doctoral Dissertation, University of Karadeniz Teknik, Trabzon, Turkey.

Aldrich, J. E., \& Thomas, K. R. (2005). Evaluating Constructivist Beliefs Teacher Candidates. Journal of Early Chilhood Teacher education, 25, 339-347. https://doi.org/10.1080/1090102050250408

Bay E., İlhan, M., Aydın, Z., Kinay, İ., Yiğit, C., Kahramanoğlu, R., et al. (2014). An Investigation of Teachers' Beliefs about Learning. Croatian Journal of Education, 16(3), 55-9.

Bayder S. C., \& Bulut, S. (2002). Importance of Teachers' Belıefs About Nature of Mathematics And Teaching of Mathematics in Mathematics Education. Hacettepe University Journal of Education, 23, 62-66.

Bektaş, M., \& Horzum, M. B. (2012). Otantik Öğrenme (2. Bask1). Ankara: Pegem Akademi.

Boz, Y., Aydemir, M., \& Aydemir, N. (2011). 4th, 6th, and 8th Grade Turkish Elementary Students' Epistemological Beliefs. Elementary Education Online, 10(3), 1191-1201.

Büyüköztürk. Ş. (2011). Sosyal Bilimler İçin Veri Analizi El Kitabı (15.Bask1).Ankara: Pegem Akademi Yay.

Can, B., \& Arabacioğlu S. (2009). The Observation of The Teacher Candidates' Epistemological Beliefs According to Some Variables. Procedia Social and Behavioral Sciences, 1, 2799-2803. https://doi.org/10.1016/j.sbspro.2009.01.497

Chan, K. W. (2004). Preservice Teachers' Epistemological Beliefs and Conceptions about Teaching and Learning: Cultural Implications for Research in Teacher Education. Australian Journal of Teacher Education, 29(1), 1-13. http://dx.doi.org/10.14221/ajte.2004v29n1.1

Chan, K. W., \& Elliott, R. G. (2004). Relational analysis of personal epistemology and conceptions about teaching and learning. Teaching and Teacher Education, 20, 817-831. https://doi.org/10.1016/j.tate.2004.09.002

Chan, K. W., Tan, J., \& Khoo, A. (2007). Pre-service Teachers' Conceptions about Teaching and Learning: A Closer Look at Singapore Cultural Context. Asia-Pacific Journal of Teacher Education, 35(2), 181-195. https://doi.org/10.1080/13598660701268593

Deryakulu, D., \& Büyüköztürk, Ş. (2005). The Re-Examination of the Epistemological Beliefs Questionnaire's Factor Structure: Comparing Epistemological Beliefs in Terms of Gender and Program Type. Eurasian journal of Educational Research, 18, 236-252.

Deryakulu, D. (2006). Epistemolojik İnançlar. In Kuzgun, Y. ve Deryakulu, D. (Ed.), Eğitimde Bireysel Farklılıklar (içinde 261-289). Ankara: Nobel Yayın Dağıtım. 
Duru, S. (2014). The Effect of Constructivist and Traditional Learning Environment on Student Teachers' Educational Beliefs. Pamukkale University Journal of Education, 36, 15-28. https://doi.org/10.9779/PUJE599

Erdem, M., \& Arkün Kocadere, M. (2015). Development of Constructivist Learning Belief Scale. Elementary Education Online, 14(4), 1260-1275.

Eren, A. (2006). Examining The General and Domain-Specific Epistemological Beliefs of Undergraduates. Unpublished Doctoral Dissertation, University of Abant İzzet Baysal, Bolu, Turkey.

Eren, A. (2009). Examining the Teacher Efficacy and Achievement Goals as Predictors of Turkish Student Teachers"e Conceptions about Teaching and Learning. Australian Journal of Teacher Education, 34(1), 69-87. https://doi.org/10.14221/ajte.2009v34n1.6

Eren, A. (2010). Consonance and Dissonance Between Turkish Prospective Teachers' Values and Practices: Conceptions About Teaching, Learning, And Assessment. Australian Journal of Teacher Education, 35(3), 27-48. https://doi.org/10.14221/ajte.2010v35n3.3

Frankel, J. R., Wallen, N. E., \& Hyun, H. H. (2012). How to Design and Evaluate Research in Education (8th Edition). New York: McGraw Hill.

İlhan, M., Çetin, M., \& Kinay, İ. (2015). The Turkish Adaptatıon of Beliefs About Standardized Tests Scale (Basts): The Validity and Reliability Study. Mustafa Kemal University Journal of Social Sciences Institute, 12(29), 161-189.

Kagan, D. M. (1992). Implications of Research on Teacher Belief. Educational Psychologist, 27, 65-90. https://doi.org/10.1207/s15326985ep2701_6

Kaleci, F. (2013). The Relationship Between Pre-Service Mathematics Teacher's Epistemological Beliefs And Their Learning And Teaching Styles. Journal of Research in Education and Teaching, 2(4), 23-32.

Karabulut, E. O., \& Ulucan, H. (2012). The Examination of Physical Education Teacher Candidates' Scientific Epistemological Beliefs in Terms of Different Variables. Journal of Sports and Performance Researches, 3(2), $39-44$.

Karakuş, F. (2006). The Effect of Constructivist Learning And Authentic Assessment Approach on Social Studies Teaching Students' Academic Achievement Retention and Attitudes Towards Social Studies. Unpublished Doctoral Dissertation, University of Çukurova, Adana, Turkey.

Kinay, İ., \& Bağçeci, B (2017). The Examination of Influence of Authentic Assessment Approach on Prospective Teachers' Beliefs Towards Learning and Partacipative Assessment. Dumlupinar University Journal of Social Sciences, 52, 16-32.

Kinay, İ., \& Karataş, K. (2017). The Investigation of The Relationship Between Teachers' Beliefs Towards Learning And Beliefs Towards The Standard Tests. European Journal of Education Studies, 3(10), 159-175.

Kinay, İ., \& Han, B. (2017). Investigating the Prospective Teachers' Beliefs about Learning. Journal of Education and Practice, 8(30), 82-91.

Kinay, İ., \& Ardıç, T. (2017). Investigating Teacher Candidates' Beliefs about Standardized Testing. Universal Journal of Educational Research, 5(12), 2286-2293. https://doi.org/10.13189/ujer.2017.051219

Koçak, C., Ulusoy, F. M., \& Önen, A. S (2012, Haziran). Öğretmen Adaylarının Kimlik İşlevlerinin ve Eğitim İnançlarının İncelenmesi. X.Ulusal Fen Bilimleri ve Matematik Eğitimi Kongresi, Niğde.

Luft, J. A., \& Roehrig, G.H. (2007). Capturing Science Teachers' Epistemological Beliefs: The Development of the Teacher Beliefs Interview. Electronic Journal of Science Education, 11(2), 38-63.

Mansour, N. (2009). Science Teachers' Beliefs and Practices: Issues, Implications and Research Agenda. International Journal of Environmental \& Science Education, 4(1), 25-48.

Mohamed, R., \& Othman, L. (2017). Authentic Assessment in Assessing Higher Order Thinking Skills, International Journal of Academic Research in Business and Social Sciences, 7(2), 466-476. http://dx.doi.org/10.6007/IJARBSS/v7-i2/2021

Moorcroft,T. A., Desmarais, K. H., Hogan, K., \& Berkowitz, A. R. (2000). Authentic Assessment in the Informal Setting: How It Can Work for You. The Journal of Environmental Education, 31(3), 20-24. https://doi.org/10.1080/00958960009598641 
Nespor, J. (1987). The Role of Beliefs in the Practice of Teaching. Journal of Curriculum Studies, 19(4), 317-328. https://doi.org/10.1080/0022027870190403

Olfos, R., \& Zulantay, H. (2007). Reliability and Validity of Authentic Assessment in a Web Based Course. Educational Technology \& Society, 10(4), 156-173.

Önen, A. S. (2012). Effects of Educational Beliefs on Attitudes Towards Using Computer Technologies. H. U. Journal of Education, 43, 353-361.

Öztuna Kaplan, A. ve Macaroğlu Akgül, E. (2009). Prospective Elemantary Science Teachers' Epistemological Beliefs. Procedia Social and Behavioral Sciences, 1(1), 2529-2533. https://doi.org/10.1016/j.sbspro.2009.01.446

Pajares, M. F. (1992). Teacher Beliefs and Educational Research: Cleaning Up a Messy Construct. Review Of Educational Research, 62(3), 307-332. https://doi.org/10.3102/00346543062003307

Pallant, J. (2005). SPSS Survival Manual: A Step by Step Guide to Data Analysis Using SPSS for Windows. Australia: Australian Copyright.

Sang, G. Y., Valcke, M., van Braak, J., \& Tondeur, J. (2009). Investigating Teachers' Educational Beliefs in Chinese Primary Schools: Socioeconomic and Geographical Perspectives. Asia-Pacific Journal of Teacher Education, 37(4), 363-377. https://doi.org/10.1080/13598660903250399

Slavin, R. E. (2017). Öğrenci öğrenmelerinin Ölçülmesi (Çev. G. Yüksel). G. Yüksel (Ed.), Eğitim Psikolojisi Kuram Uygulama (10. Bask1) içinde (318-319). Ankara: Nobel akademi Yayıncılık

Schermelleh-Engel, K., Moosbrugger, H., \& Müller, H. (2003). Evaluating the Fit of Structural Equation Models: Tests of Significance and Descriptive Goodness-of-Fit Measures. Methods of Psychological Research Online, $8(2), 23-74$.

Schommer, M. (1998). The Influence of Age and Education on Epistemological Beliefs. British Journal of Educational Psychology, 68, 551-562. https://doi.org/10.1111/j.2044-8279.1998.tb01311.x

Svinicki, M. D. (2004). Authentic Assessment: Testing in Reality. New Directıons for Teaching and Learning, 100, 23-29. https://doi.org/10.1002/tl.167

Şahin, Ç., ve Karaman, P. (2013). Preservice Elementary Teachers' Assessment Beliefs. H. U. Journal of Education, 28(2), 394-407.

Tsai, C. C. (2002). Nested Epistemologies: Science Teachers' Beliefs of Teaching, Learning and Science. International Journal of Science Education, 24(8), 771-783. https://doi.org/10.1080/09500690110049132

Tutar, H. (2016). İnançlar ve Değerler. H. Tutar (Ed.), Davranış Bilimleri Kavramlar ve Kuramlar (3.Baskı) (içinde 305-334). Ankara: Seçkin Yayıncılık.

Woolley, S. L., Benjamin, W. J. J., \& Woolley, A. W. (2004). Construct Validity of A Self-Report Measure of Teacher Beliefs Related to Constructivist and Traditional Approaches to Teaching and Learning. Educational and Psychological Measurement, 64(2), 319-331. https://doi.org/10.1177/0013164403261189

Zheng, H. (2009). Review of Research on EFL Pre-Service Teachers' Beliefs and Practices. Journal of Cambridge Studies, 4(1), 73-81. https://doi.org/10.17863/CAM.1579 